Pamiętnik Literacki 2018, 3, s. 93-106

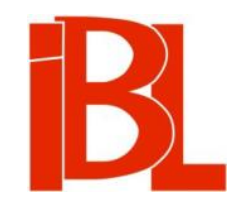

\title{
Miłosz i Eliasz
}

\author{
Adam Regiewicz
}


Pamiętnik Literacki CIX, 2018, z. 3, PL ISSN 0031-0514

DOI: $10.18318 / \mathrm{pl} .2018 .3 .7$

ADAM REGIEWICZ Akademia im. Jana Długosza, Częstochowa

\section{MIŁOSZ I ELIASZ}

Piosenka o końcu świata jest jednym z najbardziej rozpoznawalnych tekstów poetyckich Czesław Miłosza. Napisana „w samym środku okupacyjnych ciemności” ${ }^{1}$, stanowi wyraz zawierzenia nadziei wbrew nadziei. Niektórzy badacze ujrzą w tym wierszu próbę otrząsania się $z$ przedwojennego katastrofizmu ${ }^{2}$, wytyczającego drogę żagarystom i im podobnym. Inni dostrzegą typową dla awangardy lat trzydziestych aluzyjność, która pozwalała twórcom sięgać po nawiązania do Apokalipsy św. Jana (przypomnijmy tu choćby Juliana Tuwima czy Konstantego Ildefonsa Gałczyńskiego).

Apokalipsa w poezji Miłosza pojawia się nie w wymiarze społecznym czy obyczajowym, nawet nie estetycznym, ale na poziomach metafizycznym oraz egzystencjalnym. Poeta przedstawia świat jako ład gotowy na katastrofę, realizująca się $\mathrm{w}$ wymiarze dosłownym w trakcie wojny, i schodzi $\mathrm{z}$ przestrzeni symbolicznej do historii ${ }^{3}$. Nie dziwi zatem użyta w wierszu forma czasu teraźniejszego, która podkreśla naoczność owego końca. Dzień końca świata „staje się już” ${ }^{4}$. A jednak wiersz Miłosza otwierający cykl Głosy biednych ludzi uruchamia inną sferę znaczeń, niż można by się tego spodziewać po wywołanym w tytule odniesieniu.

\section{Piosenka o końcu świata w dyskursie interpretacyjnym}

Dla uporządkowania dalszego wywodu przypomnijmy najważniejsze rozpoznania miłoszologów w tym zakresie. Poeta buduje bardzo jasny obraz świata, nasycony zmysłowościa, spokojem, pogoda 5 . Przywołane składniki tego świata uderzają swoją naturalnością i prostotą: pszczoła, kwiat, rybak, delfiny, wróble, wąż. Podobnie dalej: kobiety z parasolkami, pijak na trawniku, sprzedawcy warzyw na ulicy wyznaczaja rytm codzienności. Obrazy są tyleż proste, co plastyczne, wręcz - jak

1 A. Fiut, Moment wieczny. O poezji Czesława Miłosza. Warszawa 1993, s. 105.

2 Zob. J. Kott, O katastrofizmie. „Odrodzenie” 1945, nr 18.

3 J. Trznadel (w: B. Chrząs tow s ka, Poezje Czesława Miłosza. Warszawa 1982, s. 90) zwraca uwagę na przeniesienie przez Miłosza języka codzienności do opisu wojny, przedstawienie jej jako „swoistej zwykłości”. Odrzuca tu symboliczność czy skomplikowaną metaforykę awangardy na rzecz realistycznej oszczędności.

4 Cz. Miłos z, Piosenka o końcu świata. W: Wiersze wszystkie. Kraków 2011, s. 206.

5 Zob. A. Ok o pi én-Sła wińs k a, „Przedmieście” jako inna „Piosenka o końcu świata”. Przyczynek do opisu sztuki poetyckiej Czesław Miłosza. W zb.: Poznawanie Miłosza. 2. Część pierwsza 19801998. Red. A. Fi u t. Kraków 2000, s. 215. Pierwodruk: „Pamiętnik Literacki” 1987, z. 1. 
zauważył Kazimierz Wyka - filmowe. Oko kamery zatrzymuje się nad kolejnymi scenami, przenosząc je z rzeczywistości do tekstu. Te osobne ujęcia, choć oddzielone od siebie cięciami, łączą się w dość spójną narrację pogodnego nastroju. Trudno nie dostrzec, że za obrazem spokoju i piękna świata zwyczajnie kryje się poetycka wizja, nie zaś okupacyjna rzeczywistość lat czterdziestych ${ }^{6}$.

Kontrast między poetyckim wyobrażeniem a historycznym porządkiem świata zaznaczył poeta już w samym tytule. Muzyczność piosenki, kojarząca się z czymś miłym, kojacym, przyjemnym, jest zestawiona z pełnym dramatyzmu wydarzeniem „końca świata”. Jan Błoński zauważa jednak, że perspektywa końca zarysowana zostaje w wymiarze teologicznym czy eschatologicznym ${ }^{7}$. Tym samym badacz wyprowadza interpretację wiersza na poziom pozahistoryczny, zmierzając ku lekturze hermeneutycznej, powiązanej z egzystencjalnym doświadczeniem końca.

Z takim ujęciem zgadza się także Aleksander Fiut, który czyta ostatnie zdanie wiersza - „Innego końca świata nie będzie” - właśnie z punku widzenia chrześcijańskiej koncepcji czasu:

koniec świata dokonuje się jakby bez przerwy, bowiem jest wciąż możliwy i stale potencjalnie obecny w sakralnym wymiarze ludzkiej egzystencji. Paradoks bycia chrześcijaninem [...] na tym właśnie polega, że aktem wiary człowiek zdolny jest wznieść się ponad czas historyczny, równocześnie w nim pozostając ${ }^{8}$.

W owym rozpoznaniu pobrzmiewa nauka św. Pawła, który podkreśla ważkość czasu pośredniego, rozpiętego między pierwszym a drugim (paruzją) przyjściem Chrystusa. „Oto teraz czas upragniony, oto teraz czas zbawienia” (2 Kor 6, 25) ${ }^{9}$ pisze apostoł, akcentując znaczenie „trzeciego” przyjścia dokonującego się indywidualnie w historii każdego człowieka. Życie chrześcijańskie jest przede wszystkim świadomym doświadczaniem teraźniejszości, nad którą odbywa się Sąd ${ }^{10}$. Dlatego Miłosz wielokrotnie w wierszu używa perspektywy temporalnej (anaforyczne „dopóki” czy permanentnie stosowany czas teraźniejszy opisywanych zdarzeń). W tej teraźniejszości, przyjmującej w Piosence o końcu świata obraz codzienności czy zwyczajności (zwróćmy uwagę, że ową zwyczajność świata Miłosz wyraża za pomocą języka mowy potocznej), objawia się też egzystencjalny i metafizyczny wymiar śmierci ${ }^{11}$. Ta także zostaje wpisana w porządek życia.

Przywołane dla porządku konstatacje na temat Piosenki o końcu świata pozwalają wysnuć kilka wniosków, na bazie których można zaproponować nowy trop interpretacyjny owego klasycznego utworu. Po pierwsze, to, co pisze Miłosz, powinno być rozpatrywane równocześnie na więcej niż jedna płaszczyznach. Jeszcze jako

6 Zob. Chrzastows ka, op. cit., s. 86.

7 J. Błońs ki, Wzruszenie, dialog i madrość. W zb.: Poznawanie Miłosza. Studia i szkice o twórczości poety. Red. nauk. J. Kw i a tk ow s ki. Kraków-Wrocław 1985, s. 375.

8 Fiut, op. cit., s. 105.

9 Tu i w całym artykule, jeśli nie zaznaczono inaczej, cytując z Biblii korzystam z wyd.: Pismo Święte Starego i Nowego Testamentu $w$ przekładzie z języków oryginalnych. Oprac. Zespół Biblistów Polskich [...]. Biblia Tysiaclecia. Wyd. 5, na nowo oprac. i popr. Poznań 2003.

10 Podobne rozpoznanie czyni F. Kafka w Procesie. Homilia w katedrze metaforycznie przedstawia los człowieka stojącego przed Prawem. Poszczególni ludzie na Sąd wzywani są indywidualnie. Nie ma ucieczki ani usprawiedliwienia. Każdemu przyporządkowana jest brama, przez którą musi przejść.

11 Zob. Błońs ki, op. cit., s. 376. 
żagarysta domagał się od literatury, by ta w swojej zawartości sięgała do wszystkich składników, i podkreślał współzależności treściowe, językowe i kulturowe ${ }^{12}$. Nic dziwnego, że też w analizowanym wierszu kontekst historyczny zostaje przeniknięty przez eschatologię czy religię $\mathrm{w}$ ogóle, porządek zbiorowy (społeczny) zderzony jest $z$ wymiarem jednostkowym, egzystencjalnym. Po drugie, utwory Miłosza powinno czytać się komparatystycznie, to znaczy w kontekście innych. Poeta zostawia ślady, na których podstawie należałoby zaproponować ciekawą ścieżkę lektury: Piosenka o końcu świata i Gdzie wschodzi słońce i kędy zapada, a także Oeconomia divina lub Przedmieście. Można czytać wiersze Miłosza w relacji do innych wypowiedzi lirycznych - jak chociażby proponuje Błoński, zestawiając wiersz z Fragmentem Juliana Przybosia, czy pozostali artyści zderzający tekst wileńskiego poety Z ówczesnymi „małymi apokalipsami” żagarystów. Lektura komparatystyczna pozwala na odkrywanie znaczeń dotąd ukrytych lub niejasnych, jak nawiązanie do koncepcji eschatologicznej Emanuela Swedenborga ${ }^{13}$. Tym samym zrozumiałe staje się zdanie, jakim Błoński rozpoczyna swoją wypowiedź na temat poezji Miłosza, która, jak pisze: „Pozornie przystępna, [...] nie odsłoniła czytelnikom ani części swoich zagadek"14. Taka próbę odsłonięcia chciałbym zaproponować w dalszych fragmentach interpretacji wiersza Piosenka o końcu świata, stosując metodę czytania komparatystycznego.

Punktem odniesienia dla omawianego utworu będzie postać biblijna, a zarazem cała tradycja żydowska, która wydarzenia $\mathrm{z}$ nią związane interpretuje w kluczu egzegetycznym. Chodzi mianowicie o scenę oczekiwania Eliasza na śmierć. Postaci proroka nie wprowadzono tu przypadkowo. Tradycja judeochrześcijańska uznaje w nim symbol zapowiedzi mesjańskich. Jest to zatem figura eschatologiczna, odwołująca się do wymiaru paschalnego.

\section{Prorok czasu ostatecznego}

W scenie Przemienienia Pańskiego na górze Tabor Eliasz pojawia się wraz z Mojżeszem obok Chrystusa jaśniejącego Boskością, uwiarygodniając Jego posłannictwo od Ojca (Mt 17, 1-8). Moment przebóstwienia Jezusa, któremu towarzyszy Eliasz, nie jest tu przypadkowy, wskazuje bowiem na Boską chwałę. Tradycja Izraela widzi w Eliaszu proroka, który nie zaznał śmierci, ale został wzięty do nieba. Jedna z legend przedstawia tę scenę $\mathrm{w}$ kontekście walki $\mathrm{z}$ aniołem śmierci, pragnącym go pochwycić. Eliasz wymyka się wszakże, strącając go $z$ siebie i wzlatując w niebo. Bóg w związku z tym powie: „Tylko po to stworzyłem niebo, żeby Elija mógł do niego wstapić" 15 .

Niezwykłe wstapienie Eliasza do nieba trzeba odczytywać w perspektywie całej historii postaci, która w swojej działalności wciąż zaskakuje. Kilkukrotnie na kartach Ksiag Królewskich pojawia się, by ukazać moc Pana, a następnie znika z oczu

Zob. W. P. Szy mań s ki, Żagary i żagaryści. W: Od metafory do heroizmu. Z dziejów czasopism literackich $w$ Dwudziestoleciu międzywojennym. Kraków 1967.

Zob. Fiut, op. cit., s. 106.

Błoński, op. cit., s. 363.

M. J. B. G o ri o n, Żydowskie legendy biblijne. Przeł., oprac. R. R. Still er. Wyd. 2, popr. Katowice 2009, s. 418. 
wszystkich. Tak dzieje się, gdy obwieszcza wieloletnia suszę, gdy rozprawia się z prorokami Baala, wreszcie kiedy zapowiada karę dla pary królewskiej: Izebel i Achaba, za zamordowanie Nabota. Eliasz po objawieniu się mocy Boga usuwa się w cień. Dlatego postać proroka w tradycji żydowskiej wiąże się z oczekiwaniem Dies Domini. Eliasz ma być zwiastunem nadchodzących dni ostatecznych: ogłaszać karę, a zarazem czas łaski Bożej (zob. Ml 3, 23-24). Przyjścia Eliasza Izrael wypatruje szczególnie $\mathrm{w}$ momentach silnego zniewolenia, widząc $\mathrm{w}$ tym proroku obietnicę mesjańską. Nic dziwnego zatem, że czas przyjścia Chrystusa koresponduje z czasem mesjańskiego oczekiwania na Eliasza ${ }^{16}$.

W rozmowie z uczniami Chrystus odnosi się do tego oczekiwania, przypominając dwie kluczowe sprawy. Eliasz to prorok czasów ostatecznych, a więc jego obecność zwiastuje Dzień Sądu, kiedy objawi się chwała Boga. W teologii chrześcijańskiej jest to czas związany z paruzją, powtórnym przyjściem Chrystusa. Tym samym żydzi i chrześcijanie w podobny sposób wypatruja „znaku Eliasza”, zapowiadającego dni ostateczne. Druga kwestia pozostaje czas.

Św. Jan Chryzostom, odwołując się do listów św. Pawła, przypomina, że tradycja mówi o dwóch przyjściach Chrystusa: o tym, które już nastapiło, oraz o przyszłym. To pierwsze poprzedził św. Jan Chrzciciel, nazwany przez Chrystusa - ze względu na podobieństwo posłannictwa - Eliaszem (Mt 11, 14; 17, 12-13). Drugie przyjście dokona się „przy końcu dni” zapowiedzianych właśnie przez Eliasza. Jednak nie chodzi tu o tego samego Eliasza, ale o proroka występującego w jego funk$\mathrm{cji}^{17}$, który naucza w podobnym duchu. Ów wątek pojawia się na kartach Pisma Świętego wielokrotnie, chociażby podczas rozmowy Gabriela z Zachariaszem Archanioł wskazuje na podobna nature Jana Chrzciciela i Eliasza (Łk 1, 16-17) lub wtedy, gdy Elizeusz przejmuje część ducha Eliasza po wcześniejszym wybraniu Elizeusza na swego następcę (2 Krl 2,7-13).

Figura Eliasza odsłania zatem dość istotne tropy z perspektywy dalszej interpretacji wiersza Miłosza: czasu ostatecznego oraz ducha prorockiego, który do owego czasu przygotowuje. Opisane tu napięcie między pierwszym a drugim przyjściem (Chrystusa i Eliasza) powinno zostać skonfrontowane $z$ koncepcja „trzeciego

16 Wielokrotnie na kartach Ewangelii próbuje się konfrontować figurę Eliasza z Jezusem, czy to w scenie wyznania wiary św. Piotra w Cezarei Filipowej, gdy Chrystus pyta, za kogo ludzie Go uważają, czy też na krzyżu, kiedy słowa „Eloi Eloi lema sabachthani” (Mk 15, 34) zostają odczytane jako wezwanie Eliasza (Mk 15,35-36). Zob. F. Ri en e c k e r, G. Mai e r, Leksykon biblijny. Red. nauk. wyd. pol. W. Chrostowski. Przeł. D. Irmińska. Uzup. przekł. J. Kruczyńska. Warszawa 2001, s. 207.

17 Zob. Św. Jan Chryzostom, Homilie na „Ewangelię według św. Mateusza”. Cz. 2: Homilie 41-91. Przeł. A. Baron, J. Kry stynia c ki. Oprac., przypisy A. B a ro n. Kraków 2001, s. 188: „już wcześniej im powiedział: „On jest Eliaszem, który ma przyjść“ (Mt 11, 14). Tu zaś mówi, że już przyszedł i że $(17,11 B)$ Eliasz przyjdzie i przywróci wszystko. Nie przerażaj się i nie myśl, że w tych słowach kryje się jakiś błąd, skoro raz mówi, że przyjdzie, a raz - że już przyszedł. Wszystko to jest prawdą. Kiedy mówi: Eliasz przyjdzie i przywróci wszystko, mówi o właściwym Eliaszu i mającym wtedy nastąpić nawróceniu Żydów. Gdy zaś mówi: $(17,12)$ Eliasz już przyszedł, nazywa Jana Eliaszem ze względu na podobieństwo ich posłannictwa. Prorocy także nazywali każdego ze znakomitych królów Dawidem, a Żydów książętami sodomskimi, synami Etiopów, a to ze względu na sposób postępowania. Podobnie jak Eliasz będzie poprzednikiem drugiego przyjścia, tak Jan był poprzednikiem pierwszego". 
przyjścia” wspomnianego przez św. Pawła w Drugim Liście do Koryntian. Między przyjściem Chrystusa a czasem Jego powrotu upływa czas pośredni, o którym mówi: „oto teraz dzień zbawienia” (2 Kor 6, 2b). Ów czas pośredni, jak naucza Kościół, pozostawiono na nawrócenie, dany został do dyspozycji „Reszcie” i poganom. Powinien być uważany za krótki, naznaczony próbami i cierpieniami, które przygotowują przyszłą chwałę. Koniec się zbliża, podobnie jak dzień pełnej jasności, trzeba więc czuwać, bo nadchodzi Pan! - trzeba być „przepasanym” i dobrze używać pozostałego czasu, aby się zbawić oraz pomóc zbawić się innym, zdajac na Boga sprawę ostatecznych rozrachunków ${ }^{18}$. Czas pośredni to zarazem czas teraźniejszy, on bowiem zawsze się aktualizuje i dokonuje w danym momencie historycznym (psalm 95 〈w. 7b〉 podkreśla: „Obyście usłyszeli d zi s i a j głos Jego [...]”, zwracając uwagę na dziejące się „teraz”), a jednocześnie czas eschatologiczny, gdyż „teraz” jest momentem zbawienia. Teologia podkreśla, że dzień zbawienia to dzień ostateczny, zapowiadający przyjście Pana i koniec tego wszechświata. Sąd nad światem dokonuje się w każdym momencie, dla każdego indywidualnie.

Wprowadzenie do dalszej analizy kategorii czasu pośredniego nie może być traktowane jako rodzaj „atrakcjonu” interpretacyjnego. Trzeba by na niego spojrzeć jako na element konstytutywny dla konstrukcji tekstu Miłosza. Zanim jednak tego dokonamy, spróbujmy skonfrontować Eliasza z tym czasem pośrednim, a więc czasem zbawienia, który rozgrywa się w perspektywie indywidualnej. Najlepiej widać to w ucieczce Eliasza przed pragnieniem zemsty Izebel w związku z wymordowaniem na górze Karmel jej proroków Baala. Ścigany przez rydwany królewskie (scena odwołuje się do pogoni faraona za ludem wybranym po wyjściu z Egiptu), Eliasz chroni się na pustyni. „Jego ucieczka szybko staje się podróżą poza zwyczajny świat, co symbolizuje pozostawienie za soba towarzyszy i pokarmu oraz pielgrzymka na miejsce święte" ${ }^{19}$ - tym miejscem jest góra Horeb, gdzie niegdyś Bóg objawił się Mojżeszowi i później Chrystus został przemieniony, stąd wszystko, co tam się wydarza, warto odczytywać w perspektywie symbolicznej.

\section{Szept zamiast gromu}

Gdy Eliasz pojawia się na Horebie, jest skrajnie wycieńczony. Wchodzi do groty i tam zasypia. To jeden $z$ wielu snów, w które prorok ucieka. Eliasz - od momentu, kiedy zbiegł na pustynię przed wysłannikami Izebel - zdradza oznaki wyczerpania duchowego, a nawet depresji ${ }^{20}$. Składa taka deklarację: „Odbierz mi życie, bo nie jestem lepszy od moich przodków" (1 Krl 19, 4). Pismo dwukrotnie wspomina scenę zatrzymania się proroka pod janowcem: najpierw w pozycji siedzącej, potem leżącej. Postawy przyjęte przez ciało Eliasza w takiej kolejności świadczą wyraźnie

Zob. komentarz do 2 Kor 6, 2 w Biblii Jerozolimskiej (Przekł., wstęp, przypisy, komentarze i marginalia zespół. pod kier. A. Cholewińskiego, Z. Kiernikowskiego. Red. merytor. K. Strzała. Poznań 2006, s. 1628).

191 Księga Królewska. W zb.: Katolicki komentarz biblijny. Red. nauk., wyd. oryg. R. E. Brown, J. A. Fitzmyer, R. E. Murphy. Red. nauk. wyd. pol. W. Chrostowski. Przeł. K. Bardski [i in]. Warszawa 2004, s. 282.

20 Zob. D. Si a n o ż ę c ka, Eliasz. Kiedy nie chce mi się żyć, czyli Depresja powołanego. Kapłaństwo widziane oczami kobiety. Kraków 2016, s. 123-129. 
o jego pograżeniu się w kryzysie. Sam janowiec zaś to krzew pustynny, który w symbolice odnosi się do cierpienia i ludzkiego grzechu i w tym konkretnym przypadku jest znakiem smutku, jaki przeżywa Eliasz. Dlatego Bóg wysyła Anioła, aby go obudził, nakarmił i wysłał na górę Horeb. Prorok dociera do niej po 40 dniach marszu, skrajnie wyczerpany, na granicy śmierci. W tym momencie go spotykamy.

Eliasz ma za sobą trudne doświadczenia: ogłaszanie roku klęski, pojedynek Z prorokami Baala, wytracenie przeciwników, ucieczkę przed zemstą Izebel. Z drugiej strony, uświadamia sobie całkowity bezsens swojej misji. Izrael nie tylko się nie nawrócił, ale jeszcze doznał prześladowania (eksterminacja Bożych proroków w odwecie za śmierć kapłanów Baala). Eliasz patrzy na rozwalone ołtarze i bałwochwalstwo, myśląc o porażce religii i wiary. Przychodzi na górę Horeb, miejsce dla Izraela kluczowe, aby nadać życiu jakiś sens. Prorok liczy, że Bóg objawi teraz swoją chwałę wobec przewrotnego ludu i dokona pomsty za jego niewierność. Oczekuje podobnej jak za czasów Mojżesza teofanii - ognia i gromów (zob. Wj 3, 1-6; $33,18-34,9)$.

Scena spotkania $z$ Bogiem na Horebie wydaje się zasadnicza dla zrozumienia wspomnianego tu czasu eschatologicznego. Przywołajmy ją w tym miejscu:

Wtedy rzekł: „Wyjdź, aby stanąć na górze wobec Pana!” A oto Pan przechodził. Gwałtowna wichura rozwalająca góry i druzgocąca skały 〈szła〉 przed Panem; ale Pana nie było w wichurze. A po wichurze - trzęsienie ziemi: Pan nie był w trzęsieniu ziemi. Po trzęsieniu ziemi powstał ogień: Pan nie był w ogniu. A po tym ogniu - szmer łagodnego powiewu. Kiedy tylko Eliasz go usłyszał, zasłoniwszy twarz płaszczem, wyszedł i stanął przy wejściu do groty. A wtedy rozległ się głos mówiący do niego: „Co ty tu robisz, Eliaszu?" (1 Krl 19, 11-13).

Na początku warto zwrócić uwage na ruch towarzyszacy spotkaniu Eliasza z Bogiem. Prorok już od dłuższego czasu przebywa w jednym miejscu. Przeżywając zwątpienie w sens swego powołania, Eliasz nie ma chęci nigdzie wyruszać, dlatego Pismo wymienia dwie jego postawy: siedzacą bądź leżącą. Oznaczają one gotowość na śmierć. Być może, wezwanie na góre prorok traktuje nawet jako pewien rodzaj konfrontacji, która zakończy cierpienie jego i całego świata. W przeciwieństwie do Eliasza - Bóg jest ruchem, zawsze przechodzi, czy to w postaci obłoku, czy słupa ognia, jak w opisanych wydarzeniach z Księgi Wyjścia.

W przywołanym kontekście tradycji nie dziwią zatem zjawiska meteorologiczne, w których Eliasz doszukuje się obecności Jahwe. Pierwsza wspomniana zostaje wichura. Autor podkreśla gwałtowność wiatru, który ma ogromną siłę, mogąca rozbijać skały. Sam wiatr jest zjawiskiem dość znaczacym dla tamtejszego klimatu: zachodni przynosi deszcz i ochłodzenie, wschodni, wiejacy z pustyni - wysusza roślinność i potrafi wywołać kilkumiesięczny brak opadów. Oba wiatry stanowią więc symbol przemijania, śmierci, która przychodzi wraz z nimi. Nie dziwi zatem, że wielokrotnie na kartach Pisma wiatr utożsamiany jest z Karą Bożą. Eliasz spodziewa się takiego oblicza Boga ${ }^{21}$, które ukaże się nad niewiernym narodem. Ale w wietrze nie ma chwały Pańskiej.

21 Może warto przy okazji wspomnieć, że Pismo wyraźnie odcina się w tym miejscu od wierzeń greckich oddających wiatrom cześć Boską. Ich wyobrażenie łączyło postać ludzką z anielskimi skrzydłami, upodobniając je do semickich postaci anielskich. W takim kontekście można by czytać żydowskie opowieści, w których gwałtowna wichura jest dziełem wysłanych przez Boga aniołów. Zob. W. Ko- 
Równie oczywiste w tym kontekście eschatologicznym w swoim dramatycznym przebiegu i interpretacji katastroficznej wydaje się zjawisko trzęsienia ziemi. Podobnie jak wiatry - wstrząsy skorupy ziemskiej są właściwe dla terenów syryjskich i palestyńskich. W interpretacji teologicznej stanowią znak towarzyszacy ważnym wydarzeniom, w tym teofanii: jak ustanowienie Prawa na Synaju czy śmierć Chrystusa na krzyżu ${ }^{22}$. Moment wstrząsu jest fundamentalny dla określenia relacji między Stwórca a stworzeniem - człowiekiem. Trzęsienie ziemi ukazuje bowiem potęgę Boga wobec znikomości, niemożności złapania równowagi, uchwycenia się czegoś pewnego na ziemi - charakterystycznych dla ludzi. Ten znak stanowi kwintesencję kruchości egzystencji, stąd pojawia się w kontekście zbliżającego się czasu ostatecznego. Apokalipsa przedstawia trzęsienie ziemi jako nieodłączną zapowiedź zbliżającego się sądu nad światem. Takiego też oczekuje Eliasz, a jednak Boga nie ma w tym wydarzeniu.

Trzecim znakiem jest ogień. To jeden $z$ najstarszych symboli solarnych, a zarazem jeden $z$ kluczowych żywiołów wszechświata ${ }^{23}$. We wszystkich kulturach silnie związał się $z$ kultem rytualnym czy to w postaci ofiar całopalnych, czy jako znak sacrum, np. w scenie płonącego krzaku Mojżesza. Widząc ogień, Eliasz znajduje się dokładnie w takim samym miejscu co niegdyś Mojżesz, gdy spotyka się z Bogiem twarza w twarz. Ogień zatem uobecnia Boga, Jego potęgę, która objawia się tak w okazywaniu pomocy (słup ognisty w nocy prowadzacy Izraelitów), jak i wymierzaniu kary ${ }^{24}$. Ta właśnie jest znakiem oczekiwanym przez proroka. Ogień ma tu być wyrazem gniewu Pańskiego w czasie ostatecznym, gniewu, który pożera grzeszników (Pwt 32, 22), zarazem zaś czynnością konieczną do oczyszczenia kul$\mathrm{tu}^{25}$. Eliasz czuje się rozczarowany. Nie dokonało się nic, co spodziewał się zobaczyć. Nie widział ani gromów. ani ognia, ani potopu, ani zniszczenia.

Nagle następuje zmiana perspektywy. Daje się słyszeć szmer, zjawisko już nie wizualne, ale audialne (1 Krl 19, 12). Eliasz rozpoznaje Boga w „szmerze łagodnego powiewu”. Tekst hebrajski używa tu sformułowania „cichy” albo „spokojny, szepczacy głos"26. A zatem nie trzęsienie ziemi, grad ognia, lecz ciche i spokojne objawienie się chwały Boga, który przychodzi sądzić ziemię. W ten sposób daje się On poznać indywidualnie Eliaszowi. Bóg okazuje się czuły i delikatny, jak muśnięcie wiatru na policzku w wiosenny dzień. Trudno nie skojarzyć haptyczności owego doświadczenia $z$ sytuacją kochanków obdarzających się dotykiem. I jeszcze ten szept także konotuje czułość i szczególny rodzaj intymnej zażyłości między zakochanymi, tu: między Bogiem a człowiekiem. Eliasz zasłania twarz w odpowiedzi na głos niczym kobieta chcąca uchodzić za skromną. Ten gest, poza wymiarem religijnym, który nakazywał zasłaniać głowę, ma jeszcze sens psychologiczny - jest

pa li ń s ki, Słownik mitów i tradycji kultury. Wyd. 4. Warszawa 1991, s. 1272. - G o r i o n, op. cit., s. 418.

Zob. Rienecker, Ma i er, op. cit., s. 818.

Zauważmy, że dwa inne żywioły: ziemia i powietrze, zostały wymienione przed chwilą.

Zob. Rienecker, Maier, op. cit., s. 565.

25 Do tego obrazu odwoła się później św. J a n w Apokalipsie (8, 5-7), mówiąc o ogniu z ołtarza Pańskiego, który anioł ciska na ziemię i który trawi trzecią część ziemi. 
wezwaniem do życia ukrytego, tzn. „cichego”27. Bóg uczy Eliasza wyrażania siebie nie poprzez burze, gromy, trzęsienia ziemi i ogień, a więc znaki gorliwości oraz kary, ale przez czułość i delikatność.

Wówczas pada kluczowe i bardzo symboliczne pytanie „Co ty tu robisz, Eliaszu?” (1 Krl 19, 9b). Wydaje się ono fundamentalne dla samego proroka, każe mu bowiem zastanowić się nad życiem, przemyśleć dotychczasową swoja egzystencję. To jest pytanie Sądu. Przypomina ono struktura inne - z Księgi Rodzaju (3, 9), gdy po grzechu człowiek ukrywa się przed Bogiem i słyszy: „Adamie, gdzie jesteś?” Podobnie jak pytanie skierowane do Eliasza, to zadane Adamowi stawia go w świetle prawdy. Mówiąc inaczej, pytanie samo w sobie już obnaża sytuację, w jakiej znalazł się prorok, nie musi się on do niego ustosunkowywać. Bóg zna odpowiedź, ale chce wyrwać Eliasza z kryzysu, jaki ten przeżywa. Przychodzi ze swoim sądem, a sąd ten odbywa się indywidualnie, o czym przypomina oznajmienie Eliasza: ,ja sam tylko zostałem [...]" (1 Krl 19, 14b).

\section{Lektura podwójna}

Pierwsze zdanie wiersza sytuuje opis wydarzenia w czasie pośrednim, wyrażonym przez św. Pawła: „Oto teraz czas upragniony, oto teraz czas zbawienia”. Poeta podkreśla teraźniejszy wymiar dnia ostatecznego czy to poprzez odwołanie explicite („W dzień końca świata”, „staje się już”), czy też poprzez użycie odpowiedniego czasu (np. „krąży”, „naprawia”, „skacza”, „ma”, „ida”, „zasypia, „nawołuja”, „podpływa”, „trwa”, „odmyka”, „nawiedza”, „się rodza”). Warto zauważyć, że dzięki kontekstowi dnia poeta wprowadza także do sytuacji eschatologicznej światło, którego w opisach katastroficznych zazwyczaj brakuje, stąd w wierszu odniesienia do tego, co błyszczy, co złote czy żółte, albo wprost jaśniejące: słońca, księżyca. Nawet noc jest rozjaśniona gwiazdami. Oczywiście, semiotyka światła poprzez symbolikę odsyła czytelnika do sacrum, ale także do wiedzy, prawa i nieprzemijalności Boga. Ponadto określenie „noc gwiaździsta” wyraźnie nawiązuje do Kantowskiej koncepcji prawa moralnego ${ }^{28}$ zasadzonego w każdym człowieku. Tym mocniej podkreśla ona indywidualny, egzystencjalny sens dobiegającego końca. „Czas zbawienia” stanowi moment indywidualny. Każdy zostanie wezwany na sąd sam.

Teofania w wierszu jest prawie niedostrzegalna. Sygnalizują ją zjawiska natury, podobnie jak ma to miejsce w scenie wyjścia Eliasza i Mojżesza na górę Horeb. Symbolikę sakralną, czy nawet chrystologiczną, zawierają niektóre z przywołanych figur zwierzęcych: pszczoła, delfin, wąż i wróbel ${ }^{29}$, a także rybak - postać niemal

Wyrażenie „życie ciche” odnosi się do ośmiu błogosławieństw z Kazania na Górze, gdzie wymienia się „cichych” jako tych, którzy zdobywają niebo swoją pokorą (Mt 5, 5).

28 Chodzi tu o wypowiedź I. Kanta z Krytyki praktycznego rozumu (Przekł., przedm., przypisy J. G ał e c ki. Wyd. 2. Warszawa 1984, s. 256): „Są dwie rzeczy, które napełniają duszę podziwem i czcią, niebo gwiaździste nade mną i prawo moralne we mnie. Są to dla mnie dowody, że jest Bóg nade mną i Bóg we mnie".

29 Pszczoła jako jeden $\mathrm{z}$ najbardziej uniwersalnych symboli sakralnych, spotykanych w różnych kulturach, kojarzona jest zazwyczaj $\mathrm{z}$ łącznikiem między światem ziemskim a duchowym. W tradycji chrześcijańskiej odnosiła się do wartości miłości, pracy i miłosierdzia, stąd szybko stała się 
ewangeliczna. Druga strofa jest już opisem bliższym przeżywania codzienności, która w swej beztrosce również konotuje „czas zbawienia”.

Najbardziej znacząca w prezentowanym ujęciu wydaje się zwrotka trzecia, uwypuklająca rozbieżność projekcji i aktualnych wydarzeń. Zaakcentowany tam zostaje paradoks czasu przyszłego, dziejącego się „teraz”. Zawieszenie kategorii czasu przyszłego jest poniekąd zrozumiałe, jeśli wziąć pod uwagę perspektywę historyczną, w której pisany jest wiersz. To w końcu środek okupacji, wojny, stanowiącej „apokalipsę spełnioną, a wręcz, co podkreśla Miłosz - wydarzającą się. Jeśli przyjać za Martinem Heideggerem rozumienie kategorii wydarzenia, okazuje się ono działaniem poruszającym, nie pozostawiającym nikogo bez reakcji. Samo słowo - ów „dar”, rodzaj prezentu, podarunku - też sugeruje darmowość dziania się. Jest w nim zawarta pewna pozytywna konotacja, swego rodzaju pozytywna energia, której Eliasz doświadcza w powiewie wiatru.

Kolejna uwaga, wynikająca $z$ rozdziału tych dwóch momentów, wiąże się z postawą wobec końca. Poeta stosuje tu powtórzenie „A którzy...”, określając za jego pomocą „strażników moralności”. Chętnie widzieliby się oni po stronie samego Boga wymierzającego sprawiedliwość. Po drugiej stronie pisarz usytuował „siwego staruszka, który byłby prorokiem, / Ale nie jest prorokiem, bo ma inne zajęcie”. Miłosz przeciwstawia poważne (naznaczone wybraniem) powołanie prorockie - czynności ogrodniczej (podwiązywania pomidorów). Zderzenie ze sobą tych postaw nabiera głębszego znaczenia, jeśli przeczytamy je w perspektywie tradycji żydowskiej.

Ogrodnicy zajmowali poślednie miejsce w układzie społecznym Izraela, mimo że pielęgnowanie ogrodu należało do czynności naznaczonych szczególnym sensem, na co zwraca się uwagę w Księdze Rodzaju. Wszak Adam, zarządzajacy ogrodem Eden, był nazwany pierwszym ogrodnikiem. Figura ta widnieje na kartach Pisma jeszcze wielokrotnie, chociażby w Pieśni nad Pieśniami, w której pojawia się postać Oblubieńca, wchodzącego „do swego ogrodu” $(5,1)$, gdzie znajduje się Oblubienica, aby napełnić Ją miłością ${ }^{30}$. Konotacja w wierszu nie jest zatem przypadkowa, w ostatniej bowiem scenie widzimy elementy pejzażu podobne do tych, które przed chwila przywołaliśmy w kontekście spotkania Eliasza z Bogiem: delikatny powiew wiatru i towarzysząca owej sytuacji delikatność.

Interpretacja zyskuje na znaczeniu, gdy wprowadzimy do sceny ogrodu jeszcze

znakiem chrystologii. Można utożsamić ją też z postacią Chrystusa Króla - Pantokratora, przychodzącego panować nad światem w czasie ostatecznym.

Delfin określany „królem ryb” jest symbolem potęgi. W tradycji chrześcijańskiej kojarzy się go z Chrystusem, który przeprawia dusze ze śmierci do życia. W tym kontekście delfin stał się prefiguracją śmierci i zmartwychwstania.

Wąż to jeden z najstarszych symboli sakralnych. Zazwyczaj utożsamiany ze złem, ale warto pamiętać, że w Księdze Liczb węża miedzianego przybito do pala, aby uratować Izraelitów. Tym samym wąż już w Starym Testamencie staje się zapowiedzią śmierci krzyżowej Chrystusa.

Wróblowi, mimo antycznych skojarzeń erotycznych, tradycja judeochrześcijańska przypisuje znaczenia samotności, pokory i skromności. W tradycji ustnej Kościoła wróbel stanowi symbol egzystencji ludzkiej, która pojawia się na chwilę na świecie i znika. Zob. J. C. Co o per, Zwierzęta symboliczne i mityczne. Przeł. A. Kozłowska-Ryś, L. Ryś. Poznań 1998, s. 45, 218-219, 285-286, 300.

30 Zob. S. F a u s ti, Rozważaj i głoś „Ewangelię”. Wspólnota czyta „Ewangelię wg św. Jana”. Przeł. B. A. G a n c ar z. Kraków 2009, s. 613 n. 
trop chrystologiczny. Po pierwsze, wiąże się on z samą figura ogrodnika. W Ewangelii św. Jana (20, 11-18) Chrystus po zmartwychwstaniu ukazuje się właśnie w ogrodzie, gdzie spotyka Go św. Maria Magdalena ${ }^{31}$. Początkowo nie rozpoznaje Mistrza i myli Go z ogrodnikiem. To wydarzenie niezwykle symboliczne, cechuje się bowiem odniesieniami do Pieśni nad Pieśniami. Chrystus - Ogrodnik objawia się jako Oblubieniec, stąd cała ta scena jest pełna czułości: Maria wszak rozpoznaje Zmartwychwstałego po głosie, po bezpośredniości, po czułości, z jaką się zwraca do niej. Spotkanie z Bogiem, to, które dokonuje się między pierwszym a drugim przyjściem, odznacza się niezwykłą delikatnością.

Trop chrystologiczny nie ogranicza się tylko do figury ogrodnika. Przyjrzyjmy się gestowi semiotycznemu „siwego staruszka” przewiązującego pomidory. Zauważmy samą czynność. Pomidor należy do rodziny roślin psiankowatych, które hoduje się dla owoców - soczystych i dużych jagód. W uprawie osiaga zazwyczaj 1,5 metra wysokości, co wymaga podparcia go drewnianym palikiem lub tyczką. W tym celu przewiązuje się niektóre odgałęzienia, by podtrzymać ciężar owoców. Ich barwa jest pierwotnie i najczęściej czerwona.

W ogrodniczej konstrukcji można dostrzec kilka analogii do krzyża. Pionowe usytuowanie palika i więzy, którymi przypięta jest roślina, przywodzą na myśl sytuację Chrystusa przybitego do krzyża. Silnie przemawiają także same owoce czerwone jagody pomidorów, wywołując skojarzenie $\mathrm{z}$ ranami Ukrzyżowanego. Podobieństwo to świetnie oddaje znak paschalnej świecy: grona wbijane w paschał, odnoszące się do pięciu ran Chrystusa, przypominają kształtem i kolorem małe pomidorki. Co więcej, jeśli sięgnąc do symboliki roślin, pomidor opisywany jest jako miłość. Już sama nazwa odwołuje nas do sensu przenośnego. W języku francuskim „pomme d'amour” kojarzy owoc z ,jabłkiem miłości”, w języku włoskim zaś „pomo d'oro" (złote jabłko) odsyła nas ponownie do Księgi Rodzaju, drzewa poznania Dobra i Zła ${ }^{32}$. Po raz kolejny wraca zatem symbol drzewa-pala-krzyża, na którym dokonuje się zbawienie świata.

Tyczka $z$ czerwonymi pomidorami wywołuje jeszcze jedno skojarzenie chrystologiczne - paschał. Ogromna świeca jest znaczona gronami. Ów ważny element liturgii światła, rozpoczynajacy noc paschalna, symbolizuje Chrystusa Zmartwychwstałego, który przychodzi. Teologia chrześcijańska podkreśla aspekt eschatologiczny - Bóg „tej nocy” przechodzi. Pierwszym chrześcijanom towarzyszyło przekonanie, że paruzja nastąpi jeszcze za ich życia, stąd nadzieja wyczekiwania była bardzo namacalna. Czy za gestem przewiązywania pomidorów nie skrywa się symbol paschalnej świecy istniejący w obrzędach Wielkiej Nocy? Wszak twórczość Miłosza, jak przyznaje sam poeta, naznaczona jest kontekstem religijnym ${ }^{33}$, ma wiele odniesień do liturgii katolickiej ${ }^{34}$.

Sąd odbywający się nad światem dokonuje się z perspektywy ofiary Chrystusa.

Zob. A. Re gi i w i c z, „Noli me tangere...” O potrzebie dotykania sensu. Krytyka somatyczna wobec kerygmatycznej interpretacji tekstu. „Teksty Drugie” 2015, nr 6.

32 Zob. M. Rejew s ki, Pochodzenie łacińskich nazw roślin polskich. Warszawa 1996.

33 Zob. Th. Merton, Cz. Miłos z, Listy. Kraków 2003, s. 108.

34 Zob. W. F el s k i, Podmiot liryczny poezji Czesława Miłosza wobec liturgii katolickiej. „Napis” 2010, nr 16. 
Ta zaś zwraca uwagę nie tyle na konieczność cierpienia, ile na miłosierdzie, o czym przypomina wypowiedź ewangeliczna: „Chcę raczej miłosierdzia niż ofiary” (Mt 12, 7). Powtórzone przez „siwego staruszka” zdanie: „Innego końca świata nie będzie”, stanowi wręcz proklamację zbawienia obejmującego wszystkich. Jest nie tyle ironiczna, co podkreślali niektórzy interpretatorzy, ile pełna nadziei, skierowanej na miłość jako siłę napędzającą życie człowieka. Miłość - jak pokazuje Chrystus - objawia się w tym, co słabe ${ }^{35}$.

\section{Miłosz w lekturze egzegetycznej}

Zaproponowana interpretacja zrodziła się w duchu lektury egzegetycznej. Oznacza ona próbę przeniesienia technik znanych $z$ tradycji czytania Tory, pism wczesnochrześcijańskich, istniejącej do dziś w Kościele, do praktyki krytycznej, lektury literaturoznawczej ${ }^{36}$. Czytając tekst, można go potraktować jako natchniony (w sensie uniesienia poetyckiego jest to nawet zrozumiałe) ${ }^{37}$ i stosować wobec niego owe techniki. W lekturze tej łączy się to, co wynika $z$ sensu powierzchniowego, i to, co ukrywa się pod symbolami; to, co nowe i nieznane, z tym, co tradycyjne. Czytanie egzegetyczne utworu literackiego sytuuje się poza ujednoznaczniajacymi interpretacjami, poza systemami symbolicznymi, oczekując pomocy spoza tego porządku. Staje się przestrzenią spotkania $z$ nowym i nieznanym.

Dekonstruowanie miejsc teologicznych jest praca niezwykle frapująca intelektualnie. $Z$ punktu widzenia badania relacji religii (także w rozumieniu chrześcijańskim czy teologicznym) i literatury ${ }^{38}$ na tle studiów literaturoznawczych taka perspektywa pozostaje intrygująca. Proponowany tu model lektury egzegetycznej skupia się na loci theologici tekstu. Michał Paweł Markowski stwierdza, że istnieja teksty, które już w swojej kompozycji, układzie treści, w przestrzeni semiotycznej nie dają się sprowadzić do odczytania literalnego, lecz konotują otwartość na wielość sensów, domagając się lektury wielopoziomowej, angażującej nie tylko intelekt, ale i sfery emocjonalne czy duchowe. To miejsca, które niejako przywołują uwagę czytelnika, zatrzymują go, są w pewnym sensie na-znaczone interpretacyjnie, zmuszają do poszukiwania czy odkrywania ${ }^{39}$. Właśnie to możemy zaobserwować w Piosence o końcu świata.

Interpretacja podejmowana w kluczu proponowanej lektury egzegetycznej byłaby najpierw doświadczeniem osobistego spotkania ze słowem literackim, które w sposób iście kerygmatyczny oddziałuje, wyjaśnia, oświeca rzeczywistość odbior-

Merton, Miłosz, op. cit., s. 104-105.

Zob. A. Re gi ew i c z, Poza horyzontem. Eseje o sztuce czytania. (Ćwiczenia z poszukiwania sensu). Kraków 2015.

Na temat teologii słowa literackiego syntetyzujące rozpoznanie czyni J. Szy mi k (W poszukiwaniu teologicznej głębi literatury. Katowice 1994), wskazując na różne zakresy nakładających się relacji między teologią rozumianą jako „mówienie o Bogu” (zatem praktyką interpretacyjna) a literaturą mającą wszak biblijny rodowód, która rości sobie prawo do postrzegania i zgłębiania rzeczywistości. Za określeniem kierunku badań nad religią i literaturą opowiada się praktyka naukowa, w której ramach wydawane są pisma, tj. „Christianity and Literature”, „Religion and Literature”, „Literature and Theology", organizowane konferencje, kierunki studiów i specjalności.

Zob. M. P. Markowski, Przed prawem. Interpretacja, literatura, etyka. „Teksty Drugie” 2002, nr $1 / 2$. 
cy, doświadczenie egzystencjalne bowiem staje się narzędziem czytania tekstu literackiego. Nie da się ukryć, że Miłosz to twórca, dla którego Słowo stanowi niepodważalną wartość, co pozwala umieścić go w kręgu poetów kerygmatycznych właśnie. W Piosence o końcu świata sytuacja ta przybiera cechy dramatyczne. Niknięcie Słowa, jego deprecjacja udaremniająca poznanie rzeczywistości dyskwalifikuje poniekąd funkcję proroczą ${ }^{40}$. „Siwy staruszek” zdaje się nie mieć prawa głoszenia prawd ostatecznych, nie może składać świadectwa czy wygłaszać sądów. Miłosz wyraźnie zatem wiąże w wierszu kategorię Słowa z wymiarem religijnym.

Łukasz Tischner napisze w tym kontekście:

jest Miłosz jednym z najważniejszych poetów religijnych XX wieku. Poetów-chrześcijan, dodajmy. [...] wiara jako całościowe egzystencjalne zaangażowanie, które wyraża się w ufności i posłuszeństwu Słowu (na przekór dotkliwemu ciążeniu wątpienia), przenika najgłębiej twórczość Poety. To jej pulsowanie pozwala nazwać dzieło Miłosza prawdziwie chrześcijańskim ${ }^{41}$.

Możliwość poprowadzenia takiej lektury utworów lirycznych Miłosza wynika jednocześnie $z$ tropu biograficznego. Jeśli uczynimy doświadczenie osobiste poety punktem odniesienia dokonywanej egzegezy, dostrzeżemy pewną spójność wypowiedzi noblisty, przenikniętą refleksją religijną, jeśli nie teologiczną ${ }^{42}$. Wspomina o tym Błoński w kontekście wydania Traktatu teologicznego, stwierdzając, że wspólnym mianownikiem całej twórczości Miłosza jest sfera metafizyczna, jeśli nie religijna ${ }^{43}$. Tu jednak nie chodzi ani o to, by wykazywać po raz kolejny religijną warstwę znaczeń w tekście autora Kronik, ani też o przenoszenie rozpoznań późnej twórczości poety na wiersze $z$ cyklu Świat. Poema naiwne, pisane w czasie okupacji. Istotne wydaje się wszakże silne powiązanie życia $z$ doznaniami religijnymi.

Metoda egzegetyczna okazuje się o tyle ważna, że wczesny Miłosz ucieka przed jednoznacznymi obrazami religijnymi, nie ufa otwartym deklaracjom, lecz nawet je atakuje. Poeta wielokrotnie krytykuje tradycyjną obrzędowość, ludową pobożność ${ }^{44}$, podważając nie tylko doktrynę katolicka, ale i zasadność uciekania się do wymiaru religijnego ${ }^{45}$. A jednak - jak już powiedzieliśmy - myślenie Miłosza przesiąknięte jest wyobraźnią religijną. Dlatego maskując czy zagłuszając istnienie wątków i motywów chrystologicznych, ucieka się on do świata natury, do symboliki rzeczy,

Zob. Z. Zarębianka, Wtajemniczenia (w) Miłosza. Kraków 2014, s. 386.

Ł. T i s c h n e r, Dwa kroki do przodu, jeden w tył. Miłosz i chrześcijaństwo. „Apokryf” nr 16. Dodatek do „Tygodnika Powszechnego” 2001, nr 26, s. 7.

Podczas II Festiwalu Miłosza w Krakowie J. Szymik w wystapieniu Miłosz i teologia dowodził silnego związku poety $z$ teologią dogmatyczną, wykazując jak bardzo katolicka i chrystocentryczna jest jego twórczość szczególnie ta po Traktacie teologicznym. Jak zauważył Szymik, tomy Miłosza napisane w ostatnim, krakowskim okresie życia, były jednoznacznie religijne. Zob. B. Gr u s z ka - Zy c h, Na II Festiwalu Miłosza [...]. „Gość Niedzielny” 2011, nr 20. Na stronie: http://gosc.pl/ doc/865816.Jeden-w-kilku (data dostępu: 2 IV 2018).

J. Błoń s ki, Duch religijny i miłość rzeczy. „Tygodnik Powszechny” 2001, nr 47.

Pod koniec życia przeciwnie, „Ostatnim schronieniem staje się dla Miłosza wiara - idealizowanych przezeń - prostaczków: kadzidła, litanie, pieśni, ludowe rozmodlenie pod posążkiem Matki Boskiej” (I. Ka ni a, Największy triumf mędrca. „Tygodnik Powszechny” 2001, nr 47).

A. Franas ze k (Miłosz. Biografia. Kraków 2011, s. 77) pisze w biografii poety, że wpływ na odejście od Kościoła i religii w ogóle został spowodowany przez konflikt przyszłego poety z gimnazjalnym prefektem ks. L. Chomskim, wzmacniający przeżywany kryzys wiary. 
które konotuja świętośćc ${ }^{46}$. Tym samym uznaje, że najlepszy sposób uprawiania poezji religijnej stanowi ucieczka przed jednoznacznymi skojarzeniami, pełnymi wielkich liter i treści katechetycznych ${ }^{47}$.

W praktyce egzegetycznej, poza niewątpliwą potrzebą posługiwania się narzędziami wywiedzionymi $z$ semiotyki, ważne jest także sięganie do antropologii, która pozwala osadzać poszczególne elementy utworu w kontekście historyczno-kulturowym. W przypadku analizowanego wiersza Miłosza strategia ta przynosi wiele odpowiedzi. Pierwsze dwie strofy, skupiające się na rytmie życia natury, oparte na wyliczeniu zwyczajnych zachowań, procesów życiowych pełnych harmonii i porząd$\mathrm{ku}$ znajduja swoje odzwierciedlenie $\mathrm{w}$ doświadczeniu rodzinnego pobytu poety w Szetejniach. Ślady rajskiego uporządkowania, które odkrywamy w Rodzinnej Europie czy Dolinie Issy, wybrzmiewają także w Piosence o końcu świata. Miłosz wspomina nie tylko „spokojne gospodarzenie człowieka na ziemi” ${ }^{8}$, ale i spiżarnię pełną przetworów, bibliotekę czy apteczkę, gdzie na półkach stały cudownego koloru rozmaite garnuszki, a z szuflad unosiły się przeróżne ingrediencje, zapachy.

Smaki, zapachy, kolory, dźwięki i faktury objawiały się wszędzie wokół. [...] Miłosz poznał życie wiejskie, w którym od świata natury nie oddziela nas lada sklepu, folia opakowań, szyba samochodu, i zgodnie z nim kształtowała się jego wyobraźnia ${ }^{49}$.

Urywki tego zmysłowego świata Miłosz zaprezentuje w Piosence o końcu świata. Również trop Eliasza znajduje swoje uzasadnienie w biografii poety. I nie chodzi tu tylko o wspomniana już jego otwartość na tematykę religijną, ale o nawiązania do tradycji żydowskiej. Warto przypomnieć, że w latach trzydziestych XX wieku, gdy Miłosz przebywa w Wilnie, miasto to jest jednym $z$ ważniejszych centrów żydowskiego życia literacko-naukowego, choć niewolnym od stereotypowych wyobrażeń i uprzedzeń rasowych. W kontekście rozruchów inspirowanych przez środowiska endeckie poeta staje po stronie Żydów, broniąc ich przed atakami bojówkarzy ${ }^{50}$. Nie tyle o politykę jednak chodzi, ile o zdanie sobie sprawy z silnego wplywu kultury hebrajskiej na polską tradycję, czego może do końca - jako czytelnicy i spadkobiercy dziedzictwa - sobie nie uświadamiamy. Trop ten odnajdujemy w innym wierszu zatytułowanym Biedny chrześcijanin patrzy na getto z cyklu Świat. Poema naiwne:

Cóż powiem mu, ja Żyd Nowego Testamentu,

Czekający od dwóch tysięcy lat na powrót Jezusa? ${ }^{51}$

Utożsamienie siebie jako chrześcijanina $\mathrm{z}$ tradycją hebrajska jest gestem bardzo znaczącym zarówno pod względem religijnym, jak i ogólnoludzkim (humanistycznym). To deklaracja stanięcia po stronie ofiar podobna do tej z Campo di Fiori,

Cz. M i o s z w rozmowie z A. Franaszkiem i T. Fijałkowskim (Sprzeczność jest dźwignią transcendencji. „Apokryf” nr 16. Dodatek do „Tygodnika Powszechnego” 2001, nr 26) wyznaje, że przyjmuje za Mickiewiczem strategię maskowania treści religijnych.

Zob. K. Jarzyńska, Między tropieniem sacrum a postsekularyzmem. O badaniu religijnych aspektów dzieła Czesława Miłosza. „Świat i Słowo” 2015, nr 2, s. 57.

Ibidem, s. 25.

Zob. ibidem, s. 120-127.

51 Cz. Miło s z, Biedny chrześcijanin patrzy na getto. W: Wiersze wszystkie, s. 212. 
a jednocześnie odnalezienie wspólnego doświadczenia Boga i oczekiwania Mesjasza, którego przyjścia wypatrywano szczególnie w czasie „apokalipsy spełnionej”.

Innym z przykładów oddziaływania wpływu kultury żydowskiej może być widzenie Oskara Miłosza, który dla młodego Czesława stanie się na wiele lat autorytetem. Paryski stryj poety w wizji mistycznej zobaczył „anioła Jehowy” - Boga Abrahama, Boga Izaaka i Boga Jakuba, który objawia się w ogniu jak niegdyś Mojżeszowi $^{52}$. Starotestamentalne nawiązanie wydaje się aż nadto czytelne. To już nie jest Bóg filozofów czy uczonych, ale Bóg, którego można osobiście doświadczyć. Oskar Miłosz odczytał wizję jako nadanie mu godności proroka, Bożego namiestnika, który ma kontynuować drogę innego mistyka - Swedenborga. Stryj dzięki swemu widzeniu zinterpretuje Apokalipsę jako zapowiedź wielkiego kataklizmu wojennego. Nic dziwnego, że to jego postawa zafascynowała Czesława Miłosza, który w wybuchu drugiej wojny światowej dostrzegł spełniające się proroctwa odnoszące się do końca dotychczasowej rzeczywistości.

Od momentu spotkania z Oskarem Miłoszem poeta w sposób wyrazisty zacznie formułować w swoich wierszach treści religijne.

Więcej: stanie się on (czasem jawnym, czasem utajonym) obrońcą wiary w istnienie wyższego porządku i nadziei, że świat, który znamy, nie jest jedyny, że miliardy niepowtarzalnych ludzkich istnień nie giną w ciemnych wodach nicości, ich nieśmiertelne cząstki trwają po drugiej stronie czasu, czekając na ostateczne przywrócenie ${ }^{53}$.

Pełna nadziei eschatologia wydaje się bliska przesłaniu Piosenki o końcu świata.

Lektura wierszy Czesława Miłosza dokonywana w perspektywie komparatystycznej, ze świadomością toczącej się podskórnie narracji religijnej (jeśli nie teologicznej), daje możliwość odczytywania aspektów twórczości poety w szerszym kontekście. Interpretacja taka otwiera nowa perspektywę, charakterystyczną dla zwrotu postsekularnego, podkreślając złożoność relacji między religią a dyskursem nowoczesnym, a zarazem pozwala czytać dzieła noblisty wciąż na nowo, ustępując nieco miejsca samemu czytelnikowi.

\section{Abstract \\ ADAM REGIEWICZ Jan Długosz University, Częstochowa}

\section{MILOSZ AND ELIJAH}

The article analyses Czesław Miłosz's one of the most recognisable piece - Piosenka o końcu świata (A Song on the End of the World). The poem's interpretation is directed on the context of the Apocalypse and Christian eschatology. The Jewish tradition, which belongs to omitted perspectives of analysis, proves vital due to the poet's private contacts with and interests in Judaism and due to the poem's subject referring to the end of the world. In Miłosz's poem the point of reference is the Biblical prophet Elijah, a messianic figure signalling the final days. A more insightful reading of the two pieces - the Biblical and the poetic one - supported by exegesis leads to a conviction of a relation between the scene of Elijah's expecting death and Czesław Miłosz's lyrical situation of the poem. 